\title{
Bacillus mojavensis sp. nov., Distinguishable from Bacillus subtilis by Sexual Isolation, Divergence in DNA Sequence, and Differences in Fatty Acid Composition
}

\author{
MICHAEL S. ROBERTS, ${ }^{1}$ L. K. NAKAMURA, ${ }^{2}$ AND FREDERICK M. COHAN ${ }^{1 *}$ \\ Department of Biology, Wesleyan University, Middletown, Connecticut 06459-0170, ${ }^{1}$ and Microbial Properties \\ Research, National Center for Agricultural Utilization Research, Agricultural Research Service, \\ U.S. Department of Agriculture, Peoria, Illinois $61604^{2}$
}

\begin{abstract}
A number of Bacillus strains isolated from desert soil samples were shown to belong to a previously unidentified species, for which we propose the name Bacillus mojavensis. The type strain is RO-H-1 (= NRRL B-14698). On the basis of restriction digest data, $B$. mojavensis is most closely related to Bacillus amyloliquefaciens, Bacillus atrophaeus, and Bacillus subtilis. So far, B. mojavensis can be distinguished from B. subtilis only by differences in whole-cell fatty acid composition, divergence in DNA sequence, and resistance to genetic transformation between taxa (in addition to reduced genome relatedness values). Sequence divergence and sexual isolation may prove to be more useful than metabolic characteristics for delimiting cryptic Bacillus species.
\end{abstract}

Although the species most closely related to Bacillus subtilis are easily distinguished from one another by DNA relatedness data $(14,15)$, very few phenotypic criteria that distinguish these species are known. For example, only three phenotypic traits that distinguish Bacillus amyloliquefaciens from $B$. subtilis are known, and none of these traits is by itself diagnostic (11, 14). Bacillus atrophaeus has been phenotypically distinguished from $B$. subtilis only by pigmentation (15), and even the more distantly related organism Bacillus licheniformis has been distinguished from $B$. subtilis by only five metabolic traits (11). These observations suggest that, because of a lack of distinctive phenotypic characteristics, there may be species that are closely related to $B$. subtilis which have not been discovered yet.

Recent studies of genetic variation among soil isolates having $B$. subtilis-like phenotypes revealed two distinct clusters of strains; these clusters were distinguished on the basis of restriction digests of polC and $r p o B$ genes and resistance to genetic transformation across the clusters $(4,18)$. In this study, we present evidence that one of these clusters is a previously unidentified Bacillus species.

\section{MATERIALS AND METHODS}

Bacterial strains. A derivative of $B$. subtilis 168 , designated 1A2 (= NRRL B-14819) (prototrophic, rifampin susceptible), and a derivative of $B$. subtilis W23, designated 2A2 (= NRRL B-14820) (prototrophic, rifampicin susceptible), were obtained from the Bacillus Genetic Stock Center. B. amyloliquefaciens type strain ATCC 23350 (= NRRL B-14393) and B. licheniformis type strain ATCC 14580 (= NRRL NRS-1264) were obtained from the American Type Culture Collection. Type strains B. atrophaeus NRRL NRS-213, Bacillus lentimorbus NRRL B-2522 (= ATCC 14707), Bacillus popilliae NRRL B-2309 (= ATCC 14706), and B. subtilis NRRL NRS-744 (= ATCC 6051) were provided by the Agricultural Research Service Culture Collection at the National Center for Agricultural Utilization Research. (The prefix NRRL indicates that a

\footnotetext{
* Corresponding author. Phone: (203) 347-9411. Fax: (203) 344-7952. Electronic mail address: FCOHAN@EAGLE.WESLEYAN.EDU.
}

strain is maintained in the Agricultural Research Service Culture Collection at the National Center for Agricultural Utilization Research; each NRRL designation includes the prefix B-, which identifies organisms that were obtained directly from individuals or were isolated at the National Center for Agricultural Utilization Research, or the prefix NRS-, which identifies strains that were obtained from the N. R. Smith Bacillus collection.) As shown in Table 1, native Bacillus isolates were obtained from natural soil populations in the Mojave Desert of California, the Gobi Desert of Inner Mongolia, People's Republic of China, the Sahara Desert of Tunisia, and the Sonoran Desert of Arizona.

Sampling and screening for strains with the $B$. subtilis phenotype. Multiple near-surface soil samples (depth, 10 to 20 $\mathrm{cm}$; ca. $150 \mathrm{~g}$ ) were collected aseptically at each site; the distances between sampling locations at each site were at least $6 \mathrm{~m}$. As described by Cohan et al. (4), a suspension of soil was heated at $80^{\circ} \mathrm{C}$ for $10 \mathrm{~min}$ to induce spore germination and to kill vegetative cells. Soil suspensions were plated onto Tryptose blood agar base (Difco), and the emergent colonies were streaked three times for isolation. The isolates were then screened for the ability to hydrolyze gelatin, the ability to utilize citrate, the ability to reduce nitrate, and the ability to ferment L-arabinose and mannitol. According to Logan and Berkeley (11), any isolate that is positive for all five of these metabolic tests is probably a $B$. subtilis isolate or an isolate belonging to one of five other Bacillus species (B. amyloliquefaciens, Bacillus carotorum, Bacillus lentus, B. licheniformis, or Bacillus megaterium). Nakamura (15) has shown that $B$. atrophaeus is also indistinguishable from $B$. subtilis on the basis of these metabolic criteria. We determined that none of our isolates were $B$. megaterium isolates by a morphological examination of the cells and that none were $B$. atrophaeus isolates on the basis of a lack of pigmentation on TGY agar $(2,15)$. Isolates of $B$. amyloliquefaciens, $B$. carotorum, B. lentus, and $B$. licheniformis were eliminated by characterizing each isolate for its ability to utilize 49 carbohydrates (including L-arabinose and mannitol) by using API 50CHB diagnostic strips, as described by Logan and Berkeley (11). All native isolates described in this paper have a phenotype consistent with $B$. 
TABLE 1. Bacillus strains compared in this study

\begin{tabular}{|c|c|c|}
\hline Strain $^{a}$ & Source ${ }^{b}$ & History \\
\hline \multicolumn{3}{|l|}{ Group 1 strains } \\
\hline RO-B-2 (= NRRL B-14700) & 1 & F. M. Cohan, from soil, Mojave Desert, Calif. \\
\hline RO-C-2 (= NRRL B-14699) & 1 & F. M. Cohan, from soil, Mojave Desert, Calif. \\
\hline RO-H-1 ${ }^{\mathrm{T}}(=$ NRRL B-14698 $)$ & 1 & F. M. Cohan, from soil, Mojave Desert, Calif. \\
\hline RO-QQ-2 (= NRRL B-14702) & 1 & F. M. Cohan, from soil, Mojave Desert, Calif. \\
\hline RS-A-2 (= NRRL B-14701) & 1 & F. M. Cohan, from soil, Mojave Desert, Calif. \\
\hline IM-A-224 (= NRRL B-14704) & 1 & F. M. Cohan, from soil, Gobi Desert, People's Republic of China \\
\hline IM-A-312 (= NRRL B-14703) & 1 & M. S. Roberts, from soil, Gobi Desert, People's Republic of China \\
\hline IM-B-35 (= NRRL B-14705) & 1 & F. M. Cohan, from soil, Gobi Desert, People's Republic of China \\
\hline IM-B-359 (= NRRL B-14706) & 1 & M. S. Roberts, from soil, Gobi Desert, People's Republic of China \\
\hline IM-C-45 (= NRRL B-14707) & 1 & F. M. Cohan, from soil, Gobi Desert, People's Republic of China \\
\hline IM-D-69 (= NRRL B-14708) & 1 & F. M. Cohan, from soil, Gobi Desert, People's Republic of China \\
\hline IM-D-215 (= NRRL B-14709) & 1 & M. S. Roberts, from soil, Gobi Desert, People's Republic of China \\
\hline IM-E-3 (= NRRL B-14710) & 1 & F. M. Cohan, from soil, Gobi Desert, People's Republic of China \\
\hline IM-E-46 (= NRRL B-14711) & 1 & F. M. Cohan, from soil, Gobi Desert, People's Republic of China \\
\hline IM-F-1 (= NRRL B-14712) & 1 & F. M. Cohan, from soil, Gobi Desert, People's Republic of China \\
\hline IM-F-76 (= NRRL B-14713) & 1 & M. S. Roberts, from soil, Gobi Desert, People's Republic of China \\
\hline TU-A-7 (= NRRL B-14816) & 1 & M. S. Roberts, from soil, Sahara Desert, Nefta, Tunisia \\
\hline TU-A-8 (= NRRL B-14714) & 1 & M. S. Roberts, from soil, Sahara Desert, Nefta, Tunisia \\
\hline TU-A-10 (= NRRL B-14715) & 1 & M. S. Roberts, from soil, Sahara Desert, Nefta, Tunisia \\
\hline TU-B-9 (= NRRL B-14716) & 1 & M. S. Roberts, from soil, Sahara Desert, Nefta, Tunisia \\
\hline TU-D-7 (= NRRL B-14717) & 1 & F. M. Cohan, from soil, Sahara Desert, Nefta, Tunisia \\
\hline TU-E-8 (= NRRL B-14718) & 1 & F. M. Cohan, from soil, Sahara Desert, Nefta, Tunisia \\
\hline TU-E-9 (= NRRL B-14824) & 1 & M. S. Roberts, from soil, Sahara Desert, Nefta, Tunisia \\
\hline TU-F-9 (= NRRL B-14719) & 1 & M. S. Roberts, from soil, Sahara Desert, Nefta, Tunisia \\
\hline T-G-2-42 (= NRRL B-14817) & 2 & K. E. Duncan, from soil, Tumamoc Hill, Ariz. \\
\hline T-G-3-41 (= NRRL B-14818) & 2 & K. E. Duncan, from soil, Tumamoc Hill, Ariz. \\
\hline \multicolumn{3}{|l|}{ B. subtilis strains } \\
\hline 1A2 (= NRRL B-14819) & 3 & J. Lederberg \\
\hline $2 \mathrm{~A} 2(=$ NRRL B-14820) & 3 & E. W. Nester \\
\hline RO-A-4 (= NRRL B-14821) & 1 & F. M. Cohan, from soil, Mojave Desert, Calif. \\
\hline RO-E-2 (= NRRL B-14822) & 1 & F. M. Cohan, from soil, Mojave Desert, Calif. \\
\hline RO-NN-1 (= NRRL B-14823) & 1 & F. M. Cohan, from soil, Mojave Desert, Calif. \\
\hline RO-SS-1 (= NRRL B-14697) & 1 & F. M. Cohan, from soil, Mojave Desert, Calif. \\
\hline NRRL NRS-744 ${ }^{\mathrm{T}}$ & 4 & ATCC $6051^{\mathbf{T}}$ \\
\hline NRRL B-209 & 4 & \\
\hline NRRL B-356 & 4 & \\
\hline NRRL B-361 & 4 & \\
\hline NRRL B-447 & 4 & \\
\hline \multicolumn{3}{|l|}{ B. amyloliquefaciens strains } \\
\hline ATCC $23350^{\mathrm{T}}\left(=\right.$ NRRL B-14393 $\left.3^{\mathrm{T}}\right)$ & 5 & L. L. Campbell strain F from J. Fukomoto, from soil \\
\hline NRRL B-14668 & 4 & \\
\hline NRRL B-3070 & 4 & \\
\hline \multicolumn{3}{|l|}{ B. atrophaeus strains } \\
\hline NRRL NRS- $213^{T}$ & 4 & N. R. Smitih, "B. subtilis var. niger", from Colorado soil \\
\hline NRRL NRS-216 & 4 & \\
\hline NRRL NRS-363 & 4 & \\
\hline NRRL NRS-364 & 4 & \\
\hline NRRL NRS-365 & 4 & \\
\hline B. lentimorbus ATCC $14707^{\mathrm{T}}$ (= NRRL B-2522C ${ }^{\mathrm{T}}$ ) & 4 & \\
\hline \multicolumn{3}{|l|}{ B. licheniformis strains } \\
\hline $\operatorname{ATCC} 14580^{\mathrm{T}}\left(=\right.$ NRRL NRS- $\left.1264^{\mathrm{T}}\right)$ & 5 & R. E. Gordon from T. Gibson 46 \\
\hline NRRL B-642 & 4 & \\
\hline NRRL B-960 & 4 & \\
\hline NRRL B-1001 & 4 & \\
\hline NRRL B-14224 & 4 & \\
\hline B. popilliae ATCC $14706^{\mathrm{T}}\left(=\mathrm{NRRL} \mathrm{B}-2309^{\mathrm{T}}\right)$ & 4 & \\
\hline
\end{tabular}

${ }^{a}$ All group 1, B. subtilis, and type strains have been deposited in the Agricultural Research Service Culture Collection at the National Center for Agricultural Utilization Research, Peoria, Ill.

${ }^{b}$ 1, F. M. Cohan, Department of Biology, Wesleyan University, Middletown, Conn.; 2, K. E. Duncan, Department of Ecology and Evolutionary Biology, University of Arizona, Tucson; 3, D. R. Zeigler and D. H. Dean, Bacillus Genetic Stock Center, Ohio State University, Columbus; 4, L. K. Nakamura, National Center for Agricultural Utilization Research, Peoria, Ill.; 5, American Type Culture Collection, Rockville, Md.

subtilis, as described above. No more than three native isolates were obtained from any single soil sample.

Selection for spontaneous rifampin-resistant mutants. We obtained rifampin-resistant ( $\mathrm{Rif}^{\mathrm{r}}$, encoded by $r p o B$ ) mutants of each strain (to be used as donors in transformation) by streaking a sample from a single colony onto tryptose blood agar base supplemented with $10 \mu \mathrm{g}$ of rifampin (Sigma Chemical Co.) per $\mathrm{ml}$. A single rifampin-resistant colony was then 


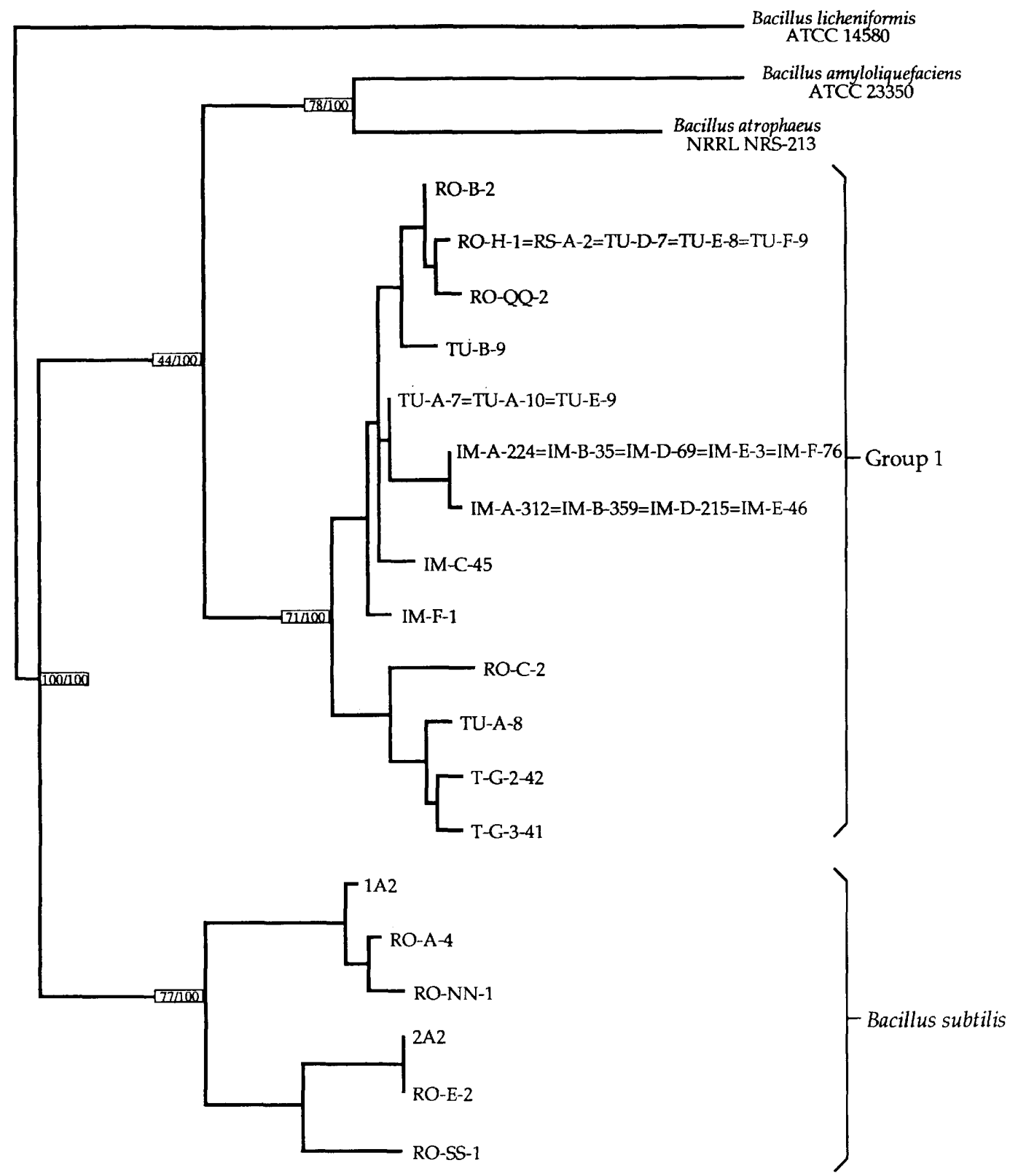

FIG. 1. Maximum-parsimony phylogeny based on a composite gene sequence including a 1,024-bp segment of gyrA, a 940-bp segment of polC, and an 808-bp segment of $r p o B$. The numbers in the boxes at the bases of the nodes indicate the number of times that each node was supported in 100 bootstrap replicates.

collected for each strain and streaked for isolation twice on tryptose blood agar base lacking rifampin. The rifampin resistance of each isolate was confirmed by plating it on tryptose blood agar base supplemented with rifampin.

Purification of genomic DNA. Genomic DNA for use in transformation experiments was obtained from a spontaneous Rif $^{T}$ mutant of each strain, as described previously (4). The procedure used for preparing highly purified DNA for reassociation measurements has been described previously (16).

Transformation. Using the protocol described by Cohan et al. (4), we induced strains to become competent for transformation in liquid cultures, and each strain was transformed to rifampin resistance with genomic DNA from its own Rif mutant (homogamic transformation) and with DNAs from Rif ${ }^{r}$
TABLE 2. Levels of nucleotide diversity within group 1 strains and within $B$. subtilis strains

\begin{tabular}{llll}
\hline \multirow{2}{*}{ Taxon } & \multicolumn{3}{c}{ Level of nucleotide diversity ${ }^{a}$} \\
\cline { 2 - 4 } & \multicolumn{1}{c}{ gyrA gene } & \multicolumn{1}{c}{ polC gene } & \multicolumn{1}{c}{ rpoB gene } \\
\hline Group 1 & $0.031 \pm 0.004(26)^{b}$ & $0.010 \pm 0.002(24)$ & $0.003 \pm 0.001(22)$ \\
B. subtilis & $0.046 \pm 0.013(6)$ & $0.045 \pm 0.013(6)$ & $0.013 \pm 0.004(6)$ \\
\hline
\end{tabular}

${ }^{a}$ Levels of nucleotide diversity within group 1 strains and within $B$. subtilis strains for a 1,024-bp segment of gyrA, a 940-bp segment of polC, and an 808-bp segment of rpoB.

${ }^{b}$ Average \pm standard error. The numbers in parentheses are the numbers of strains used. 
mutants of other strains (heterogamic transformation). We calculated transformation frequencies by determining the fraction of cells from the recipient culture that were transformed to rifampin resistance, after correcting for mutation. Sexual isolation (i.e., resistance to transformation) between a recipient and a test donor was quantified by determining the ratio of the frequency of homogamic transformation to the frequency of heterogamic transformation.

PCR amplification of DNA. A PCR was performed by using the GeneAmp protocol (Perkin-Elmer-Cetus), as described previously (4). Oligonucleotide primers were designed by using the gyr $A$ (13), polC (20), and $r p o B$ (sequence kindly provided by Kathryn Boor, Marian Duncan, and Chester W. Price) coding sequences of $B$. subtilis 168 and were synthesized by Oligos, etc., Guilford, Conn. The gyr $A$ primers extended from position 7237 to position 7260 (5'-CAG TCA GGA AAT GCG TAC GTC CTT- $3^{\prime}$ ) and from position 8261 to position 8238 (5'-CAA GGT AAT GCT CCA GGC ATT GCT-3'), yielding a 1,024-bp PCR segment. The polC primers extended from position 287 to position 310 (5'-ATT CAG GCC TCA GCG CTT TGA AGA-3') and from position 1227 to position 1204 (5'-CCG GAA TTT GTT CAC TTA GTT CCC-3'), yielding a 940-bp PCR segment. The $r p o B$ primers extended from position 1102 to position 1125 (5'-AGG TCA ACT AGT TCA GTA TGG ACG-3') and from position 1910 to position 1887 (5'GTC CTA CAT TGG CAA GAT CGT ATC-3'), yielding an 808-bp PCR segment.

Restriction digests of PCR-amplified segments. An aliquot of each PCR-amplified gene segment from each strain was subjected to restriction with each of five or more four-cutter restriction endonucleases, as described previously $(4,18)$. Briefly, restriction digests were assayed by electrophoresis on polyacrylamide gels and were stained with ethidium bromide. Fragment lengths were estimated by using a HaeIII digest of $\phi X 174 \mathrm{RF}$ (New England Biolabs) as a lane marker. On the basis of the differences in restriction digest patterns between strain 168 and each other strain, we inferred the most parsimonious set of nucleotide substitutions for pairs of strains by using the computer algorithm of Cohan et al. (4).

DNA reassociation and $\mathbf{G}+\mathbf{C}$ content determinations. The extents of DNA reassociation were determined on the basis of renaturation rates determined spectrophotometrically with a model 250 UV spectrophotometer (Gilford Systems, CIBACorning Diagnostics Corp., Oberlin, Ohio) equipped with a model 2527 thermoprogrammer (16). The equation of De Ley et al. (5) was used to calculate DNA relatedness values.

The $\mathrm{G}+\mathrm{C}$ content was estimated by the thermal melting procedure described by Mandel and Marmur (12). Escherichia coli DNA with a $\mathrm{G}+\mathrm{C}$ content of 51 mol\% was used for comparison.

Phenotypic characterization. Physiological, morphological, and metabolic characteristics (except fatty acid composition) were determined as described previously $(8,16)$. The wholecell fatty acid composition was determined by the MIDI system of Sasser (19) by using organisms grown for $24 \mathrm{~h}$ at $28^{\circ} \mathrm{C}$ on Trypticase soy broth agar. Fatty acid composition was determined for the following strains: 22 group 1 isolates (i.e., all group 1 isolates except TU-A-7, TU-E-9, T-G-2-42, and T-G3-41), 3 strains of $B$. amyloliquefaciens (the type strain, NRRL B-3070, and NRRL B-14668), 5 strains of B. atrophaeus (the type strain, NRRL NRS-216, NRRL B-363, NRRL B-364, and NRRL B-365), 5 strains of $B$. licheniformis (the type strain, NRRL B-642, NRRL B-960, NRRL B-1001, and NRRL B-14224), and 5 strains of B. subtilis (the type strain, NRRL B-209, NRRL B-356, NRRL B-361, and NRRL B-447). $B$. lentimorbus and $B$. popilliae were not characterized because
TABLE 3. Average levels of nucleotide divergence between group 1 strains and other taxa

\begin{tabular}{lccc}
\hline \multirow{2}{*}{ Taxon } & \multicolumn{3}{c}{ Level of nucleotide divergence } \\
\cline { 2 - 4 } & gyrA gene & polC gene & rpoB gene \\
\hline B. subtilis (6 strains) & $0.159 \pm 0.003^{b}$ & $0.118 \pm 0.003$ & $0.031 \pm 0.001$ \\
$\begin{array}{l}\text { B. atrophaeus NRRL } \\
\text { NRS-213 }\end{array}$ & $0.101 \pm 0.001$ & $\mathrm{ND}^{\mathrm{T}}$ & $0.054 \pm 0.001$ \\
$\begin{array}{l}\text { B. amyloliquefaciens } \\
\text { ATCC 23350 }\end{array}$ & $0.128 \pm 0.001$ & $\mathrm{ND}$ & $0.049 \pm 0.001$ \\
$\begin{array}{l}\text { B. licheniformis } \\
\text { ATCC 14580 }\end{array}$ & $0.237 \pm 0.003$ & $\mathrm{ND}$ & $0.079 \pm 0.001$ \\
\hline
\end{tabular}

${ }^{a}$ Levels of nucleotide divergence between 22 group 1 strains and strains of other Bacillus species for a 1,024-bp segment of gyrA, a 940-bp segment of polC, and an 808-bp segment of rpoB.

${ }^{b}$ Average \pm standard error based on the variance among all pairwise comparisons.

${ }^{c} \mathrm{ND}$, not determined.

their phenotypes were known to be very different from the phenotypes of $B$. subtilis-like organisms (3).

\section{RESULTS}

Phylogeny of strains. Segments of gyrA, polC, and $r p o B$ from most strains in Fig. 1 were amplified by the PCR; the exceptions were type strains $B$. atrophaeus NRRL NRS-213, $B$. amyloliquefaciens ATCC 23350, and $B$. licheniformis ATCC 14580 (amplification of polC failed with these strains). On the basis of the four-cutter restriction digests of each segment, we inferred the nucleotide substitutions of each strain from the sequence of $B$. subtilis 168 by using the computer algorithm of Cohan et al. (4). The set of nucleotide substitutions in gyrA, pol $C$, and $r p o B$ was used to construct a phylogeny of strains by using Swofford's (21) PAUP 3.1 branch-and-bound algorithm. The algorithm generated 100 most-parsimonious trees, one of which is shown in Fig. 1. The level of bootstrap support for each node of the composite phylogeny was estimated after 100 replications by using the DNABOOT algorithm in PHYLIP 3.3 (7), as indicated in Fig. 1. In all 100 most-parsimonious trees, a group of 26 strains (group 1) fell into a clade separate from $B$. subtilis, B. atrophaeus, B. amyloliquefaciens, and B. licheniformis.

DNA sequence divergence. The level of sequence divergence between strains was determined for each amplified gene from the numbers of shared and nonshared restriction sites by using equation 5.50 of Nei (17). Table 2 shows the average pairwise divergence value for each gene for pairs of group 1 strains and for pairs of $B$. subtilis strains. The average level of divergence within group 1 was similar to that observed within $B$. subtilis; the mean average level of divergence \pm standard error for all three gene segments was $0.01 \pm 0.01$ within group 1 and 0.03 \pm 0.01 within $B$. subtilis.

Table 3 shows the average level of divergence between group 1 strains and strains belonging to other taxa for each gene. The levels of sequence divergence between group 1 and its closest relatives were much greater than the average level of divergence within group 1; e.g., the average level of divergence between group 1 and $B$. subtilis for gyr $A$ was 0.16 , whereas the average level of divergence within group 1 for this gene was 0.03 .

Sexual isolation within and between taxa. Table 4 shows the frequency at which each recipient was transformed by its own Rif $^{\mathrm{T}}$ mutant's DNA (homogamic transformation frequency) and the factor by which transformation was reduced from the 


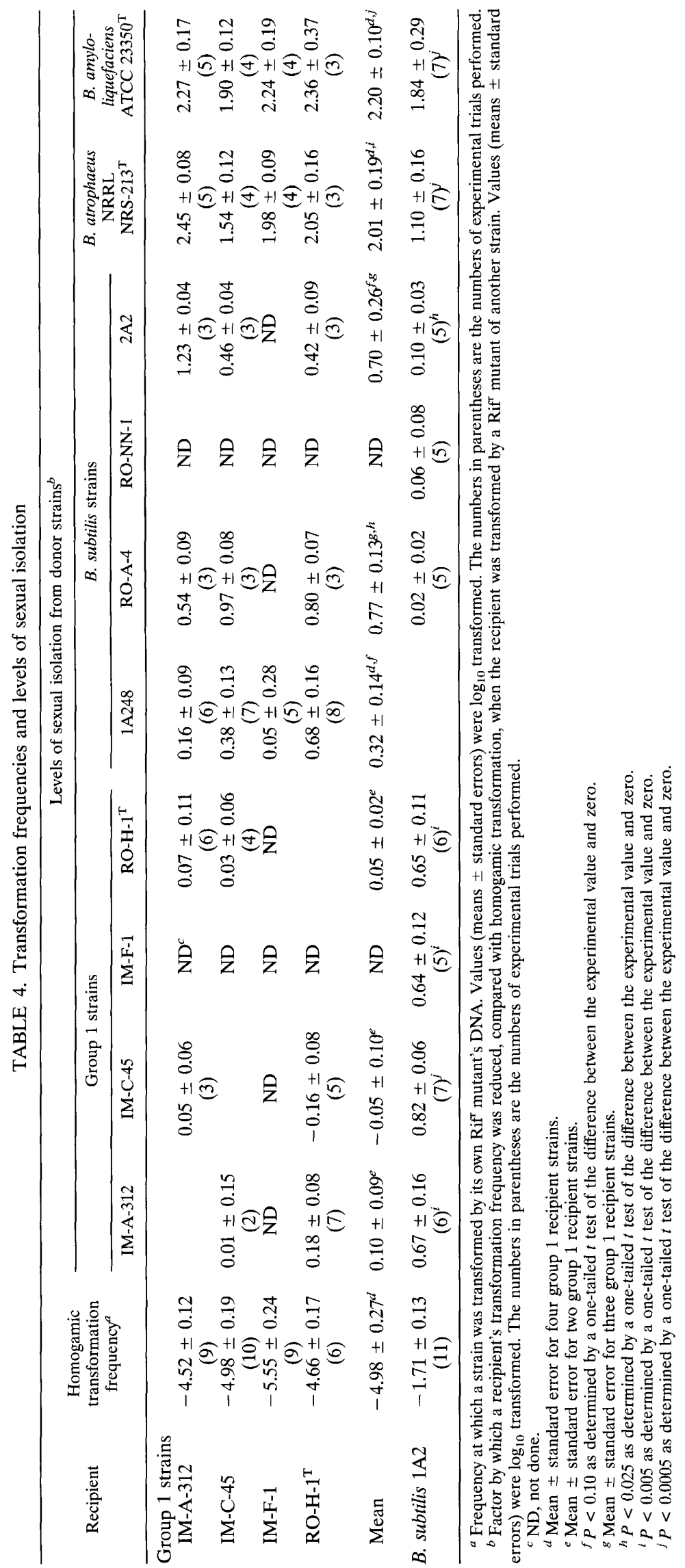


TABLE 5. Levels of DNA relatedness' of desert isolates

\begin{tabular}{|c|c|c|c|c|c|c|c|c|c|c|c|}
\hline \multirow[b]{2}{*}{ Strain } & \multicolumn{11}{|c|}{$\%$ Reassociation with DNA from ${ }^{a}$ : } \\
\hline & $\begin{array}{l}\text { B. subtilis } \\
\text { NRRL } \\
\text { NRS-744 }^{\mathrm{T}}\end{array}$ & $\begin{array}{l}\text { B. licheniformis } \\
\text { NRRL } \\
\text { NRS-1264 }\end{array}$ & $\begin{array}{l}\text { B. atrophaeus } \\
\text { NRRL } \\
\text { NRS-213 }\end{array}$ & $\begin{array}{l}\text { B. amylolique- } \\
\text { faceins } \\
\text { NRRL } \\
\text { B-14393 }\end{array}$ & $\begin{array}{l}\text { B. popilliae } \\
\text { NRRL } \\
\text { B- } 2309^{\mathrm{T}}\end{array}$ & $\begin{array}{l}\text { B. lentimorbus } \\
\text { NRRL } \\
\text { B- } 2522^{\top}\end{array}$ & RO-SS-1 & $\mathrm{RO}-\mathrm{H}-1^{\mathrm{T}}$ & IM-E-3 & IM-B-359 & TU-A-8 \\
\hline B. subtilis RO-SS- 1 & 70 & 10 & 20 & 19 & 31 & 33 & $(100)^{b}$ & 36 & 24 & 23 & 39 \\
\hline \multicolumn{12}{|l|}{ Group 1 strains } \\
\hline $\mathrm{RO}-\mathrm{H}-1^{\mathrm{T}}$ & 25 & 12 & 25 & 20 & 37 & 38 & 36 & $(100)$ & 100 & 98 & 100 \\
\hline $\mathrm{RO}-\mathrm{C}-2$ & 27 & 15 & 27 & 25 & 29 & 25 & 39 & 86 & 90 & 98 & $\mathrm{ND}^{c}$ \\
\hline RO-B-2 & 34 & 20 & 32 & 24 & 34 & 33 & 28 & 100 & 84 & 100 & 100 \\
\hline RS-A-2 & 24 & 22 & 30 & 30 & 35 & 32 & 33 & 89 & 100 & 100 & 84 \\
\hline RO-QQ-2 & 37 & 18 & 29 & 31 & 38 & 32 & 38 & 91 & 90 & 80 & 86 \\
\hline IM-A-312 & 14 & 20 & 28 & 29 & 34 & 32 & 33 & 85 & 99 & 96 & 85 \\
\hline IM-A-224 & 30 & 22 & 32 & 26 & 33 & 29 & 30 & 90 & 80 & 100 & 84 \\
\hline IM-B-35 & 32 & 24 & 30 & 28 & ND & ND & 28 & 95 & 97 & ND & ND \\
\hline IM-B-359 & 36 & 21 & 29 & 30 & 30 & 34 & 23 & 98 & 100 & $(100)$ & 100 \\
\hline IM-C-45 & 29 & 16 & 30 & 31 & ND & ND & 28 & 100 & 99 & ND & ND \\
\hline IM-D-69 & 30 & 19 & 31 & 35 & ND & ND & 30 & 93 & 88 & ND & ND \\
\hline IM-D-215 & 38 & 30 & 31 & 38 & 38 & 35 & 23 & 100 & 97 & ND & ND \\
\hline IM-E-3 & 32 & 25 & 32 & 28 & 40 & 39 & 24 & 100 & $(100)$ & 98 & 99 \\
\hline IM-E-46 & 38 & 32 & 35 & 26 & 38 & 34 & 28 & 99 & 93 & 93 & 91 \\
\hline IM-F-1 & 37 & 27 & 12 & 15 & 33 & 36 & 25 & 97 & 95 & 90 & 88 \\
\hline IM-F-76 & 37 & 29 & 13 & 14 & 31 & 35 & 17 & 92 & 91 & ND & ND \\
\hline TU-A-8 & 35 & 22 & 18 & 27 & 38 & 36 & 40 & 95 & 99 & 100 & (100) \\
\hline TU-A-10 & 31 & 24 & 20 & 32 & ND & ND & 33 & 94 & 100 & ND & ND \\
\hline TU-B-9 & 20 & 26 & 18 & 33 & 35 & 35 & 32 & 92 & 90 & 89 & 93 \\
\hline TU-D-7 & 39 & 28 & 11 & 30 & ND & ND & 32 & 99 & 94 & ND & ND \\
\hline TU-E-8 & 36 & 25 & 22 & 14 & ND & ND & 35 & 94 & 90 & ND & ND \\
\hline TU-F-7 & 33 & 19 & 25 & 20 & ND & ND & 28 & 96 & 99 & 97 & 100 \\
\hline
\end{tabular}

${ }^{a}$ Reassociation values are averages of two determinations; the maximum difference observed between determinations was $5 \%$.

"Parentheses indicate that, by definition, the reassociation value was $100 \%$.

${ }^{c} \mathrm{ND}$, not done.

homogamic frequency when other strains were used as donors (i.e., sexual isolation). (The data in Table 4 were $\log _{10}$ transformed, as described by Cohan et al. [4].) The four group 1 strains used as recipients underwent homogamic transformation at an average frequency of $1.0 \times 10^{-5}\left(=10^{-4.98}\right)$ (Table 4). This value is much lower than the homogamic transformation frequency of highly competent $B$. subtilis laboratory strain $1 \mathrm{~A} 2$ but is comparable to the average frequency obtained for wild $B$. subtilis strains $\left(5.2 \times 10^{-6}\left[=10^{-5.29}\right]\right.$; determined by using data for $22 \mathrm{~B}$. subtilis strains from the study of Cohan et al. [4]).

The levels of sexual isolation between different group 1 strains were uniformly low; strains were isolated at most by only a 1.5 -fold $\left(10^{0.18}\right.$-fold $)$ reduction in transformation when strain IM-A-312 was the donor and strain RO-H-1 ${ }^{\mathrm{T}}$ (T = type strain) was the recipient.

When the group 1 strains were used as transformation recipients, they were sexually isolated from $B$. subtilis donors. Donor DNAs from $B$. subtilis 1A248 and 2A2 yielded marginally significant reductions in transformation of 2.1 -fold $(=$ $\left.10^{0.32} ; t=2.28 ; 3 \mathrm{df} ; P<0.10\right)$ and 5.0 -fold $\left(=10^{0.71} ; t=2.67\right.$; $2 \mathrm{df} ; P<0.10)$, respectively; and DNA from $B$. subtilis RO-A-4 yielded a significant reduction of 5.9 -fold $\left(=10^{0.77} ; t=6.19 ; 2\right.$ df; $P<0.025$ ). (The significance of the difference between each $\log _{10}$-transformed sexual isolation value [e.g., 0.32] and zero was determined by a one-tailed $t$ test.) The group 1 recipients were also sexually isolated from $B$. atrophaeus and $B$. amyloliquefaciens donors; in experiments with these organisms the reductions were 102 -fold $\left(=10^{2.01} ; t=10.67 ; 3 \mathrm{df} ; P<\right.$ $0.005)$ and 158 -fold $\left(=10^{2.19} ; t=21.83 ; 3 \mathrm{df} ; P<0.0005\right)$, respectively.

Similarly, when B. subtilis $1 \mathrm{~A} 2$ was used as the recipient, it exhibited uniformly low levels of sexual isolation from $B$. subtilis donors. $B$. subtilis $1 \mathrm{~A} 2$ was significantly sexually isolated from donors in all other groups, including the group 1 strains; the average $\log _{10}$-transformed level of sexual isolation \pm standard error between group 1 donors and strain $1 \mathrm{~A} 2$ was $0.69 \pm 0.04(t=16.85 ; 3 \mathrm{df} ; P<0.0005)$ for the four group 1 donors tested.

DNA relatedness. Table 5 shows the levels of DNA relatedness of group 1 and $B$. subtilis strains to strains belonging to the following taxa: group $1, B$. subtilis, $B$. amyloliquefaciens, $B$. atrophaeus, B. lentimorbus, B. licheniformis, and B. popilliae (this list includes $B$. licheniformis and all of the species that are more closely related to $B$. subtilis than $B$. licheniformis is according to $16 \mathrm{~S}$ RNA sequence data [1]). The group 1 strains exhibited high levels of DNA relatedness (80 to 100\%) to one other but much lower levels of relatedness to the type strains of $B$. amyloliquefaciens, B. atrophaeus, B. lentimorbus, B. licheniformis, $B$. popilliae, and $B$. subtilis (DNA relatedness value range, 12 to $40 \%$ ). The levels of DNA relatedness between strain RO-SS-1 and the group 1 strains ranged from 17 to $40 \%$. A level of DNA relatedness of $70 \%$ with the type strain of $B$. subtilis identified RO-SS-1 as a B. subtilis strain.

Phenotypic characterization. Group 1 strains are indistinguishable from $B$. subtilis by any of the physiological, morphological, or metabolic tests shown in Table 6, and very few of these tests distinguish group 1 from other species. Positive oxidase activity is the only trait tested that differentiates group 1 strains from $B$. atrophaeus. The ability to ferment lactose differentiates $B$. amyloliquefaciens from group 1 strains. Propionate utilization, anaerobic growth, and a $G+C$ content of 46 mol\% separate $B$. licheniformis from the group 1 strains. Table 6 shows 15 trait differences that distinguish group 1 strains 
TABLE 6. Phenotypic comparison of 22 group 1 strains with B. subtilis, B. atrophaeus, B. amyloliquefaciens, B. lentimorbus, $B$. licheniformis, and B. popilliae

\begin{tabular}{|c|c|c|c|c|c|c|c|c|}
\hline Characteristic & Group 1 & $\begin{array}{l}\text { B. subtilis } \\
\text { RO-SS-1 }\end{array}$ & $\begin{array}{l}\text { B. subtilis } \\
\text { NRRL } \\
\text { NRS-744 }^{\mathrm{T}}\end{array}$ & 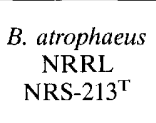 & $\begin{array}{l}\text { B. amylolique- } \\
\text { faciens } \\
\text { NRRL } \\
\text { B-14396 }\end{array}$ & B. lentimorbus ${ }^{a}$ & $\begin{array}{l}\text { B. licheniformis } \\
\text { NRRL } \\
\text { NRS-1264 }\end{array}$ & B. popilliae $e^{a}$ \\
\hline Anaerobic growth & $-b$ & - & - & - & - & + & + & + \\
\hline Catalase & + & + & + & + & + & - & + & - \\
\hline Oxidase & + & + & + & - & + & ND & + & ND \\
\hline Acetylmethylcarbinol & + & + & + & + & + & - & + & - \\
\hline Maximum growth temp $\left({ }^{\circ} \mathrm{C}\right)$ & 50 & 50 & 50 & 50 & 50 & 35 & 50 & 35 \\
\hline Minimum growth temp $\left({ }^{\circ} \mathrm{C}\right)$ & 10 & 10 & 10 & 10 & 10 & 20 & 15 & 20 \\
\hline $\begin{array}{l}\text { Growth in the presence of } \\
0.001 \% \text { lysozyme }\end{array}$ & - & - & - & - & - & + & - & + \\
\hline Growth at $\mathrm{pH} 5.7$ & + & + & + & + & + & - & + & - \\
\hline \multicolumn{9}{|l|}{ Growth in the presence of: } \\
\hline $3 \% \mathrm{NaCl}$ & + & + & + & + & + & - & + & ND \\
\hline $5 \% \mathrm{NaCl}$ & + & + & + & + & + & - & + & - \\
\hline $7 \% \mathrm{NaCl}$ & + & + & + & + & + & - & + & - \\
\hline $10 \% \mathrm{NaCl}$ & + & + & + & + & + & - & + & - \\
\hline \multicolumn{9}{|l|}{ Acid produced from: } \\
\hline Glucose & + & + & + & + & + & + & + & + \\
\hline Arabinose & + & + & + & + & + & - & + & - \\
\hline Xylose & + & + & + & + & + & - & + & - \\
\hline Mannitol & + & + & + & + & + & - & + & + \\
\hline Lactose & - & - & - & - & + & ND & - & ND \\
\hline Starch hydrolysis & + & + & + & + & + & - & + & - \\
\hline \multicolumn{9}{|l|}{ Utilization of: } \\
\hline Citrate & + & + & + & + & + & - & + & - \\
\hline Proprionate & - & - & - & - & - & - & + & - \\
\hline Nitrate reduced to nitrite & + & + & + & + & + & - & + & - \\
\hline \multicolumn{9}{|l|}{ Production of: } \\
\hline Indole & - & - & - & - & - & - & - & - \\
\hline Hydrogen sulfide & - & - & - & - & - & - & - & - \\
\hline Dihydroxyacetone & - & - & - & - & - & - & - & - \\
\hline Phenylalanine deamination & - & - & - & - & - & - & - & - \\
\hline \multicolumn{9}{|l|}{ Decomposition of: } \\
\hline Casein & + & + & + & + & + & - & + & - \\
\hline Tyrosine & - & - & - & - & - & - & - & - \\
\hline Urea & - & - & - & - & - & ND & - & ND \\
\hline Tween 80 & - & - & - & - & - & ND & - & ND \\
\hline $\mathrm{G}+\mathrm{C}$ content $(\mathrm{mol} \%)$ & 43 & 42 & 43 & 42 & 43 & 38 & 46 & 41 \\
\hline
\end{tabular}

${ }^{a}$ Data from reference 3.

${ }^{b}+$, positive reaction; - negative reaction; ND, not done.

from B. lentimorbus and B. popilliae. Insecticidal activity, production of swollen sporangia, and an inability to grow in nutrient broth also distinguish $B$. lentimorbus and $B$, popilliae from group 1 strains (3).

All of the organisms listed in Table 6 (except B. lentimorbus and $B$. popilliae, which were not tested) fermented cellobiose, fructose, galactose, maltose, mannose, raffinose, L-rhamnose, ribose, salicin, sorbitol, sucrose, and trehalose; melibiose was not fermented by these organisms (data not shown).

The following fatty acids were the principal fatty acids found in group $1, B$. subtilis, $B$. atrophaeus, $B$. amyloliquefaciens, and $B$. licheniformis: 12-methyltridecanoic (14:0 iso), 13-methyltetradecanoic (15:0 iso), 12-methyltetradecanoic (15:0 anteiso), 14-methylpentadecanoic (16:0 iso), $n$-hexadecanoic (16:0), 15 methylhexadecanoic (17:0 iso), 14-methylhexadecanoic (17:0 anteiso), cis-5-hexadecenoic (16:1 cis5), and cis-15-methyl-7hexadecenoic (17:1 cis 7 iso) acids. cis-9-Hexadecenol was also found.

Group 1 strains could be differentiated from the other taxa on the basis of significant differences in the levels of several fatty acids (Table 7). Specifically, differences in the levels of 15:0 iso, 16:1 cis 9 alcohol, 16:0, 17:1 cis 7 iso, and 17:0 anteiso distinguished group 1 strains from $B$. subtilis; differences in the levels of 14:0 iso, 15:0 iso, 15:0 anteiso, 16:0 iso, 16:0, 17:1 cis 7 iso, and 17:0 anteiso distinguished group 1 strains from $B$. amyloliquefaciens; differences in the levels of 14:0 iso, 15:0 iso, 15:0 anteiso, 16:1 cis 9 alcohol, 17:1 cis 7 iso, and 17:0 iso distinguished group 1 strains from $B$. atrophaeus; and differences in the levels of 15:0 iso, 15:0 anteiso, 16:0, and 17:1 cis 7 iso distinguished group 1 strains from $B$. licheniformis.

\section{DISCUSSION}

The results of this study corroborated previous results $(4,18)$ which showed that group 1 strains can be distinguished from $B$. subtilis and other closely related species on the basis of DNA sequence divergence and on the basis of sexual isolation in genetic transformation experiments. A phylogeny based on restriction site variation at three conserved genes showed that the group 1 strains form a distinct clade. The divergence between group 1 and other Bacillus species is much greater than the divergence within either group 1 or $B$. subtilis. The group 1 strains were shown to be sexually isolated from all other species tested: the group 1 strains were transformed by 
TABLE 7. Cellular fatty acid compositions of group 1, B. subtilis, B. amyloliquefaciens, B. atrophaeus, and B. licheniformis strains

\begin{tabular}{|c|c|c|c|c|c|}
\hline \multirow{2}{*}{ Fatty acid } & \multicolumn{5}{|c|}{ Cellular fatty acid composition $(\%)^{a}$} \\
\hline & $\begin{array}{l}\text { Group 1 } \\
(n=22)\end{array}$ & $\begin{array}{l}\text { B. subtilis } \\
(n=5)\end{array}$ & $\begin{array}{l}\text { B. amyloliquefaciens } \\
\qquad(n=3)\end{array}$ & $\begin{array}{l}\text { B. atrophaeus } \\
(n=5)\end{array}$ & $\begin{array}{l}\text { B. licheniformis } \\
(n=5)\end{array}$ \\
\hline $14: 0$ iso & $0.98 \pm 0.24$ & $1.13 \pm 0.24$ & $2.46 \pm 0.69^{b}$ & $1.44 \pm 0.14$ & $1.31 \pm 0.44$ \\
\hline $15: 0$ iso & $22.33 \pm 3.19$ & $29.27 \pm 4.64$ & $30.50 \pm 5.93$ & $15.02 \pm 2.55$ & $28.87 \pm 2.69$ \\
\hline $15: 0$ anteiso & $42.51 \pm 1.67$ & $40.19 \pm 3.98$ & $36.48 \pm 7.88$ & $51.36 \pm 1.08$ & $37.75 \pm 2.58$ \\
\hline 16:1 cis 9 alcohol & $0.69 \pm 0.29$ & $0.23 \pm 0.35$ & $0.62 \pm 0.87$ & $1.16 \pm 0.20$ & $0.91 \pm 0.44$ \\
\hline $16: 0$ iso & $2.56 \pm 0.41$ & $2.36 \pm 0.34$ & $4.40 \pm 0.75$ & $3.10 \pm 0.61$ & $4.42 \pm 10.72$ \\
\hline $16: 1$ cis 5 & $1.74 \pm 0.40$ & $1.52 \pm 0.45$ & $2.14 \pm 0.11$ & $1.72 \pm 0.11$ & $1.53 \pm 0.24$ \\
\hline $16: 0$ & $2.05 \pm 0.41$ & $3.14 \pm 0.40$ & $4.52 \pm 0.50$ & $1.99 \pm 0.32$ & $3.91 \pm 0.53$ \\
\hline $17: 1 \mathrm{cis} 7$ iso & $3.45 \pm 0.62$ & $1.72 \pm 0.42$ & $1.67 \pm 0.61$ & $1.99 \pm 0.44$ & $1.23 \pm 0.33$ \\
\hline 17:0 iso & $8.92 \pm 1.46$ & $9.59 \pm 1.56$ & $9.01 \pm 1.34$ & $4.97 \pm 0.59$ & $6.99 \pm 1.06$ \\
\hline 17:0 anteiso & $12.53 \pm 1.89$ & $9.38 \pm 0.95$ & $7.06 \pm 2.69$ & $14.83 \pm 2.36$ & $11.30 \pm 0.93$ \\
\hline
\end{tabular}

a Means \pm standard deviations.

${ }^{b}$ Values in boldface type are values that were significantly different $(P<0.05)$ from the group 1 values as determined by $t$ tests after we corrected for multiple comparisons by the sequential Bonferroni method.

other group 1 strains at a rate that was four times higher than the rate of transformation by $B$. subtilis and more than 100 times higher than the rate of transformation by any other species tested.

The patterns of sexual isolation indicated that there is a close phylogenetic relationship between $B$. subtilis and group 1 . Table 4 shows that each of these two groups is transformed at the $r p o B$ gene at a higher rate by the other group than by any other Bacillus species tested. Moreover, B. subtilis is transformed by group 1 strains at the poorly conserved $\operatorname{trp} C$ locus at a rate of $2.0 \times 10^{-4}(4)$, while other species (B. amyloliquefaciens, $B$. licheniformis, $B$. megaterium, Bacillus pumilus) transform $B$. subtilis at this locus at rates of less than $10^{-6}(6,9,10$, 22, 23).

The group 1 strains exhibit less than $40 \%$ relatedness to strains belonging to previously described Bacillus species, but they exhibit $80 \%$ or greater relatedness to other members of the group. Such observations confirm both the cohesiveness of group 1 and the distinctiveness of the group 1 cluster from other species.

Several physiological, morphological, and metabolic traits were considered in this study, but so far the group 1 strains can be distinguished from $B$. subtilis only on the basis of whole-cell fatty acid composition. Thus, the group 1 strains fit a pattern found for other close relatives of $B$. subtilis, namely, that taxa distinguished by sequence divergence and sexual isolation are generally distinguished by very few physiological, morphological, or metabolic characteristics $(4,6,9-11,14,15,18,22,23)$. This pattern suggests that sequence divergence and sexual isolation may be more useful than metabolic characteristics for delimiting cryptic Bacillus species.

Taken together, the DNA sequence divergence, sexual isolation, and whole-genome relatedness data and the differences in fatty acid composition suggest that group 1 is a separate species genetically distinct from previously described Bacillus taxa and merits recognition as a new species, for which we propose the name Bacillus mojavensis.

Description of Bacillus mojavensis sp. nov. Bacillus mojavensis (mo.hav.en'sis.N.L. gen. n. mojavensis, coming from the Mojave Desert) vegetative cells are bacilli that are 0.5 to 1.0 $\mu \mathrm{m}$ wide by 2.0 to $4.0 \mu \mathrm{m}$ long (as determined by phasecontrast microscopy) and occur singly and in short chains. Motile. Gram positive. Forms ellipsoidal spores centrally or paracentrally in unswollen sporangia.

Agar colonies are opaque, smooth, circular, entire, and 1.0 to $2.0 \mathrm{~mm}$ in diameter after 2 days at $28^{\circ} \mathrm{C}$.
Catalase is produced. Oxidase is produced. Aerobic. Acetylmethylcarbinol (as determined by the Voges-Proskauer test) is produced. The $\mathrm{pH}$ in Voges-Proskauer broth ranges from 5.3 to 5.7. Nitrate is reduced to nitrite. Starch and casein are hydrolyzed. Citrate is utilized, but propionate is not utilized. Hydrogen sulfide, indole, and dihydroxyacetone are not produced. Egg yolk lecithin, Tween 80, and urea are not decomposed. The $\mathrm{pH}$ in litmus milk is alkaline; casein is digested.

Arginine, lysine, ornithine, phenylalanine, and tyrosine are not decomposed.

Acid but no gas is produced from L-arabinose, cellobiose, fructose, glucose, galactose, maltose, mannitol, mannose, Lrhamnose, ribose, salicin, sorbitol, sucrose, and trehalose; xylose is fermented slowly. Lactose and melibiose are not fermented.

The optimum growth temperature ranges from 28 to $30^{\circ} \mathrm{C}$, the maximum growth temperature ranges from 50 to $55^{\circ} \mathrm{C}$, and the minimum growth temperature ranges from 5 to $10^{\circ} \mathrm{C}$.

The thermal denaturation temperature for the type strain is $86.9^{\circ} \mathrm{C}$, and the $\mathrm{G}+\mathrm{C}$ content determined from this value is 43 $\mathrm{mol} \%$.

The description above is virtually identical to the descriptions of B. atrophaeus and B. subtilis. The new species can be differentiated from these previously described species by DNA relatedness data, by the extent of sexual isolation, by restriction digest analysis of selected genes, and by fatty acid analysis.

Isolated from desert soils.

The type strain is RO-H-1, which has been deposited in the Agricultural Research Service Culture Collection, Peoria, Ill., as strain NRRL B-14698.

\section{ACKNOWLEDGMENT}

This work was supported by NIH grant GM39501.

\section{REFERENCES}

1. Ash, C., J. A. E. Farrow, S. Wallbanks, and M. D. Collins. 1991. Phylogenetic heterogeneity of the genus Bacillus revealed by comparative analysis of small-subunit ribosomal RNA sequences. Lett. Appl. Microbiol. 13:202-206.

2. Atlas, R. M. 1993. Handbook of microbiological media. CRC Press, Boca Raton, Fla.

3. Claus, D., and R. C. W. Berkeley. 1986. Genus Bacillus Cohn 1872, p. 1105-1139. In P. H. A. Sneath, N. S. Mair, M. E. Sharpe, and J. G. Holt (ed.), Bergey's manual of systematic bacteriology, vol. 2. Williams \& Wilkins, Baltimore.

4. Cohan, F. M., M. S. Roberts, and E. C. King. 1991. The potential for genetic exchange by transformation within a natural popula- 
tion of Bacillus subtilis. Evolution 45:1393-1421.

5. De Ley, J. H., H. Cattoir, and A. Reynaerts. 1970. The quantitative measurement of DNA hybridization from renaturation rates. Eur. J. Biochem. 12:133-142.

6. Dubnau, D., I. Smith, P. Morell, and J. Marmur. 1965. Gene conservation in Bacillus species. I. Conserved genetic and nucleic acid base sequence homologies. Proc. Natl. Acad. Sci. USA 54:491-498.

7. Felsenstein, J. 1990. PHYLIP 3.3 manual. University of California Herbarium, Berkeley.

8. Gordon, R. E., W. C. Haynes, and C. H. Pang. 1973. The genus Bacillus. Agriculture Handbook No. 427. U. S. Department Agriculture, Washington, D.C.

9. Harford, N., and M. Mergeay. 1973. Interspecific transformation of rifampicin resistance in the genus Bacillus. Mol. Gen. Genet. 120:151-155.

10. Harris-Warrick, R. M., and J. Lederberg. 1978. Interspecies transformation in Bacillus: sequence heterology as the major barrier. J. Bacteriol. 133:1237-1245.

11. Logan, N. A., and R. C. W. Berkeley. 1984. Identification of Bacillus strains using the API system. J. Gen. Microbiol. 130:18711882.

12. Mandel, M., and J. Marmur. 1963. Use of ultraviolet absorbancetemperature profile for determining the guanine plus cytosine of DNA. Methods Enzymol. 12B:195-206.

13. Moriya, S., N. Ogasawara, and H. Yoshikawa. 1985. Structure and function of the region of the replication origin of the Bacillus subtilis chromosome. III. Nucleotide sequence of some 10,000 base pairs in the origin region. Nucleic Acids Res. 13:2251-2265.
14. Nakamura, L. K. 1987. Deoxyribonucleic acid relatedness of lactose-positive Bacillus subtilis strains and Bacillus amyloliquefaciens. Int. J. Syst. Bacteriol. 37:444-445.

15. Nakamura, L. K. 1989. Taxonomic relationship of black-pigmented Bacillus subtilis strains and a proposal for Bacillus atrophaeus sp. nov. Int. J. Syst. Bacteriol. 39:295-300.

16. Nakamura, L. K., and J. Swezey. 1983. Taxonomy of Bacillus circulans Jordon 1890: base composition and reassociation of deoxyribonucleic acid. Int. J. Syst. Bacteriol. 33:46-52.

17. Nei, M. 1987. Molecular evolutionary genetics. Columbia University Press, New York.

18. Roberts, M. S., and F. M. Cohan. 1993. The effect of DNA sequence divergence on sexual isolation in Bacillus. Genetics 134:401-408.

19. Sasser, M. 1990. Identification of bacteria by gas chromatography of cellular fatty acids. Technical Note 101. Microbial ID, Inc., Newark, Del.

20. Struck, J. C. R., D. Vogel, N. Ulbrich, and V. A. Erdmann. 1988. A dnaZX-like open reading frame downstream from the Bacillus subtilis sc-RNA gene. Nucleic Acids Res. 16:2720.

21. Swofford, D. L. 1993. PAUP: phylogenetic analysis using parsimony, version 3.1 Illinois Natural History Survey, Champaign.

22. te Riele, H. P. J., and G. Venema. 1982. Molecular fate of heterologous bacterial DNA in competent Bacillus subtilis. I. Processing of B. pumilus and B. licheniformis DNA in B. subtilis. Genetics 101:179-188.

23. Wilson, G. A., and F. E. Young. 1972. Intergenotic transformation of the Bacillus subtilis genospecies. J. Bacteriol. 111:705-716. 